\title{
THE REVIEW OF METAPHYSICS
}

\section{A PHILOSOPHICAL QUARTERLY}

VOLUME VII, No. 2. - ISSUE No. 30

\section{Contents for December 1954}

ARTICLES: William Earle, Implicit and explicit Phenomena - Robert Jordan, Time and contingency in St. Augustine - Robert Johann, The meaning of Love - Paul Weiss, Guilt, God and Perfection, II - Maurice S. Friedman, Martin Buber's Theory of Knowledge.

CRITICAL STUDIES: A. Boyce Gibson, Three Books on Plato - Irwin C. Lieb, New Studies in the Philosophy of Charles Peirce - Richard Kroner, A New Critique of Theoretical Thought - Richard M. Martin, On Woodger's Analysis of Biological Language.

DISCUSSION: William P. Alston, Simple Location.

EXPLORATION: Stuart MacClintock, Heresy and Epithet: An Approach to the Problem of Latin Averroism, II.

NOTES AND OBSERVATIONS: Robert Brumbaugh, Aristotle as a Mathematician - Sydney C. Rome, Some Formulae for Aesthetic Analysis.

ANNOUNCEMENTS

BOOKS RECEIVED

201-2 LINSLY HALL, YALE UNIVERSITY NEW HAVEN, CONNEGTICUT

\section{A BIBLIOGRAPHY OF SYMBOLIC LOGIC By ALONZO CHURCH}

A complete bibliography of symbolic logic covering the period 16661935, indexed by authors and by subjects, as it appeared in THE JOURNAL of Symbolic Logic, vol. 1, pp. 121-218, and vol. 3, pp. 178-212. On sale, in unbound form only, at $\$ 3.25$. The two parts are also on sale separately at $\$ 2.00$ for the first part and $\$ 1.25$ for the second part.

A continuation of the bibliography from January 1, 1936, is provided by reviews appearing in ThE Journal of Symbolic Logic. These reviews, which are indexed by authors biennially and by subjects at longer intervals, are designed to cover current literature in this field completely, including both books and articles in periodicals.

Orders for the Bibliography, and for the Journal, should be addressed to the Secretary-Treasurer of the Association for Symbolic Logic, Rutgers University, New Brunswick, New Jersey. 


\section{The \\ Journal of Philosophy}

Founded by Frederick J. E. Woodbridge and W. T. Bush

$A^{N}$ ORGAN of active philosophical discussion. This periodical is issued

fortnightly and permits the prompt publication of brief essays in philosophy, of timely discussions, and of reviews of current books.

Editors: Professors Herbert W. Schneider, John H. Randall, Jr., Ernst Nagel, of Columbia University.

Book editors: Henry D. Aiken, Virgil C. Aldrich, Joseph L. Blau, C. West Churchman, Harry T. Costello, John. R. Everett, Edwin Garlan, Otto F. Kraushaar, Paul O. Kristeller, Cornelius Krusé, Helmut Kuhn, Kenneth P. Landon, Harold A. Larrabee, Donald S. Mackay, V. J. McGill, Ernest A. Moody, P. Romanell, Mario M. Rossi.

$\$ 5$ a year, 26 numbers. 30 cents a copy.

515 West I 6 th Street, New York 27, N. Y.

\section{ASSOGIATION FOR SYMBOLIGLOGIG}

President: W. V. Quine, Harvard University, Cambridge 38, Massachusetts.

Vice-President: Leon Henkin, University of Calfornia, Berkeley 4, California.

Secretary-Treasurer: Joshua Barlaz, Rutgers University, New Brunswick, New Jersey.

The Association For Symbolic Logic is an international organization for the promotion of research and of critical studies in the field of formal logic. It is intended to provide a meeting ground for mathematicians and philosophers interested in this field, to encourage cooperation and mutual criticism among various groups and to promote a wider general knowledge and appreciation of current research and recent advances in this field. Membership dues are five dollars per annum payable in the currency of the United States Members may obtain information concerning the possibility of payment in European currency from Mrs. C. P. C. BethPastoor, Bernhard Zweerskade 23I, Amsterdam $Z$, The Netherlands.

Orders should be addressed to the Secretary-Treasurer of the Association for Symbolic Logic, Rutgers University, New Brunswick, New Jersey. 


\section{THE}

\section{JOURNAL}

OF

\section{SYMBOLIC LOGIC}

EDITED BY

Alonzo Church S. C. Kleene Alice A. Lazerowitz

Managing Editor: AlFons BORGERS

Consulting Editors:

$\begin{array}{lll}\text { W. Ackermann } & \text { Robert Feys } & \text { Andrzej Mostowski } \\ \text { C. A. Baylis } & \text { Frederic B. Fitch } & \text { Rózsa Péter } \\ \text { Paul Bernays } & \text { Carl G. Hempel } & \text { Barkley Rosser } \\ \text { G. D. W. Berry } & \text { Leon Henkin } & \text { Thoralf Skolem } \\ \text { Martin Davis } & \text { John G. Kemeny } & \text { A. R. Turguette }\end{array}$

Volume I9

I954

Published guarterly by the Association for Symbolic Logic, Inc. WITH THE AID OF SUBVENTIONS FROM EDWARD C. HEGELER TRUST FUND 
The four numbers of Volume 19 were issued at the following dates:

Number 1, pages 1-80, March 17, 1954.

Number 2, pages 81-160, June 17, 1954.

Number 3, pages 161-240, September 25, 1954.

Number 4, pages 241-314, January, 1955.

All numbers of this volume are copyrighted by the Association for Symbolic Logic, Inc. Reproduction of copyrighted numbers of the Journal by photostat, photo-print, microfilm, or like process is forbidden, except by written permission of the Managing Editor. 


\section{TABLE OF CONTENTS}

Leibniz's interpretation of his logical calculi. By Nicholas Rescher

Remark on identity and description in first-order axiom systems. By Theodore Hailperin . . . . . . . . . . . . . . . . . 14

A relative consistency proof. By JOSEPH R. SHOENFIELd . . . . . 21

A definition of negation in extended basic logic. By Frederic B. Fitch 29

Logical paradoxes for many-valued systems. Вy Мон SHAw-KweI 37

Proof of a conjecture of Goodman. By N. J. Fine . . . . . . . . 41

The Sheffer functions of 3-valued logic. By Norman M. Martin . . 45

Reviews . . . . . . . . . . . . . . . . 52

A system of axiomatic set theory - Part VII. By Paul Bernays . . 81

Interpretations of sets of conditions. By W. V. Quine . . . . . . . 97

On predicates in algebraically closed fields. By Abraham Robinson 103

Reviews . . . . . . . . . . . . . . . . . 115

Notices of meetings of the Association for Symbolic Logic . . . . . 152

Sixteenth meeting of the Association for Symbolic Logic. By Frederic

B. Frтси . . . . . . . . . . . . . . . 153

Abstract of papers . . . . . . . . . . . . . . 153

Elections . . . . . . . . . . . . . . . . 160

Institutional contributing subscribers to the Journal . . . . . . 160

A new symbolism for the propositional calculus. By William Tuthill PARRY ................. 161

Ideographic computation in the propositional calculus. By GERALD B. StANDLEY . . . . . . . . . . . . . . . . . . . . . . 169

An undecidable problem in the algebra of truth-tables. By JAN KALICKI 172

Quantification and the empty domain. By W. V. Quine . . . . . 177

Reduction to a dyadic predicate. By W. V. Quine . . . . . . . . 180

A generalization of the concept of $\omega$-consistency. By LEON HEN KIN . 183

A partial model for Quine's "New foundations". By VÁclav EDVARD BenEš . . . . . . . . . . . . . . . . . . 197

Improved decision procedures for Lewis's calculus $\mathrm{S} 4$ and von Wright's calculus $M$. By Alan Ross Anderson . . . . . . . 201 
TABLE OF CONTENTS

Reviews . . . . . . . . . . . . . . 215

The formalization of mathematics. By HAO WANG . . . . . . . 241

The recursive irrationality of $\pi$. By R. L. Goodstein . . . . . 267

Distributivity and an axiom of choice. By George E. Collins . . . 275

Reviews . . . . . . . . . . . . . . . . 278

List of officers and members of the Association for Symbolic Logic 305 


\section{ERRATA}

\section{VOLUME 5}

Page 84, line 23. For "upward ", read "downward *.

Page 84, line 24. For "downward ", read "upward ".

\section{VOLUME 9}

Page 59, line 24. For $y_{n}$, read $y_{m}$ (three times).

VOLUME 15

Page 66, lines 13 and 18. For "eight", read "seven ".

Page 295, line 10. For "XII 54 (1)", read "XIII 54 (1) ".

\section{VOLUME 16}

Page 98, line 28. For "Typ $c$ ", read "Typ $\tau$ ".

\section{VOLUME 17}

Page 25, lines 9 and 10 from the bottom. Theorem $\mathbf{5 . 3 2}$ is not true for weak products and should therefore read: If $\phi$ is a formula of $T^{I}$ and if for each finite set $I \phi$ is true in $T^{I}$, then $\phi$ is true in $T^{I}$ for arbitrary $I$.

Page 26. Line 4 should be deleted.

Page 209, line 12 from the bottom. For "not", read "no".

Page 295, bottom line. Delete the initial, "H."

\section{VOLUME 18}

Page iii, line 3 from the bottom. For "quaterniality ", read "quaternality".

Page v. Delete the indicated corrections to volume 16, page 98 and to volume 17, page 259.

Page vi, line 3. For "parenthesis", read "parentheses".

Page 295, line 10. The displayed formula should read:

$$
n(n-1) \ldots\left(n-p_{0}+1\right) 2^{\sum_{n-1}^{\infty} p_{n} \times n^{n}}
$$

Page 299, footnotes 29 and 35. The paper referred to is Degree of factual support by John G. Kemeny and Paul Oppenheim, Philosophy of Science, vol. 19 (1952), pp. 307-324.

Page 305, line 15 from below. Insert a left parenthesis after ' $\boldsymbol{m}$ '.

Page 307, line 16. In the displayed formula the second ' $p(H)$ ' in both the numerator and denominator should be ' $p(\bar{H})$ '.

Page 311 , line 5 from the bottom. For $H 5$, read Th. 5 .

Page 315, line 9 from the bottom of text. For [2], read [3].

Page 326, line 16 from the bottom. After "Book ", insert "Company, ".

Page 332, line 2. For "defintion ", read "definition ".

Page 360, column 1, line 12 from the bottom. For 000, read 338.

Page 363, column 1, line 8. Parentheses should be bold.

Page 366, column 2, line 1. For 336, read 337.

Page 366, column 2, line 2. For 337, read 338.

Page 366, column 2, line 4. For 337, read 338.

Page 371, column 2, lines 27 and 28. Supply hyphens at the end of each line. 
Page 372, column 1, line 13 from the bottom. For "(XVII) 222 ", read " (XVII 222) *. Page 374, column 1, line 10. Read "Vaz Ferreira ".

Page 375, column 1, line 19 from the bottom. For 337, read 338.

Page 375, column 1, last line. Add before the period at the end of the line ", 338 ".

\section{VOLUME 19}

Page 3, footnote 8, line 3 and line 9. For "proposition ", read "propositio ".

Page 8, line 20. The bold characters should be Greek capital letters lambda.

Page 14, line 1. Replace "first order " by "first-order ".

Page 14, line 5 from bottom. Replace "Robinsohn " by "Robinson ".

Page 19, line 4. Replace " $Q$ " " by " $Q$ ".

Page 19, line 13 from the bottom. Replace the second "the "by "be ".

Page 29, Last line of the first paragraph. For $K^{\prime}$, read $\mathbf{K}^{\prime}$.

Page 29, Last line of the second paragraph. For $\mathbf{K}^{\prime}$, read $\mathbf{K}$.

Page 33, line 3 from the bottom. For $f$, read $u$.

Page 40, next-to-last line of text. For $\alpha_{1} \alpha_{1}$, read $\alpha_{i} \alpha_{i}$.

Page 51, in [4]. For " 373 ", read " 393 ".

Page 62, last line. For "Göde ", read "Gödel ".

Page 69, line 25. The lightface colon should be the same as the colon on line 8 .

Page 83, line 10. The exponent of the last 2 should be $m_{k}$.

Page 95, footnote 97. For "Izvéstiyd", read "Izvestiá ", and delete the period after "Nauk".

Page 122, line 14. Insert a comma after $x_{1}$.

Page 125, line 9 from the bottom. For «Nederlandsche ", read "Nederlandse *.

Page 136, line 16 from below. For "enxtension ", read " extension ".

Page 146, lines 15-14 from the bottom. For "Boollean ", read "Boolean ".

Page 147, line 2 from the bottom. Insert a space after the comma.

Page 163, Footnote 11, end of last line. For " ist ", read " its ".

Page 164, line 27. For $\frac{1}{2}$, read $1 \frac{1}{2}$.

Page 165, Last line of text. For $p-q$, read $p \sqcap q$.

Page 218, line 17. Insert a hyphen at the end of the line.

Page 219, line 8 from below. Insert a right parenthesis at the end of the line. 


\section{Scripta Mathematica Publications}

1. Scripta Mathematica is a quarterly journal devoted to the history and philosophy of mathematics. Subscription $\$ 3.00$ per year.

2. Scripta Mathematica Library. Vol. I. Poetry of Mathematics and Other Essays, by David Eugene Smith. Vol. II. Mathematics and the Question of Cosmic Mind, by Cassius Jackson Keyser. Vol. III. Scripta Mathematica Forum Lectures. Vol. IV. Fabre and Mathematics and Other Essays, by Lao G. Simons. Price of each volume, in a beautiful silverstamped cloth binding, \$1.0o. Vol. V. Galois Lectures. Price \$1.25.

3. Portraits of Eminent Mathematicians, Philosophers, and Physicists, with Their Biographies. Portfolio I ( 13 folders), out of print. Portfolio II ( 14 folders). \$3.75. Portfolic III (13 folders). \$3.75. Portfolio IV (13 folders). \$3.75.

4. Visual Aids in the Teaching of Mathematics. Single portraits, mathematical themes in design, interesting curves, and other pictorial items. Suitable for framing and for inclusion in students' notebooks. List on request.

5. George Peacock's Treatise on Algebra. (Reprint) two volumes. \$6.50.

\section{Scripta Mathematica, Yeshiva College}

Amsterdam Avenue \& 186 St., New York City

\section{MATHEMATICS AND PLAUSIBLE REASONING}

\section{By GEORGE POLYA}

A two-volume guide to the practical art of plausible reasoning by the famous author of How to Solve It. Professor Polya uses mathematics to show how hunches and guesses play an important part in even the most rigorously deductive sciences.

Volume I. Inductions and Analogy in Mathematics 336 pages. $\$ 5.50$

Volume II. Patterns of Plausible Inference

240 pages. $\$ 4.50$

The set

$\$ 9.00$

Order from your bookstore, or

PRINCETOWN UNIVERSITY PRESS, Princetown, New Jersey 


\section{CANADIAN JOURNAL OF MATHEMATICS Journal Canadien Mathématique}

EDITORIAL BOARD

H. S, M. Coxeter, A. Gauthier, R. D. James, R. L. Jeffery, G. de B, Robinson, H. Zassenhaus with the co-operation of

R. Brauer, L. E. J. Brouwer, H. Cartan, D. B. DeLury, I. Halperin, L. Infeld, S. MacLane, M. H. A. Newman, G. Pall, B. Segre, J. L. Synge, W, J. Webber

The chief languages of the Journal are English and French.

Manuscripts for publication in the Journal should be sent to the Editorin-Chief, H. S. M. Coxeter, University of Toronto. Everything possible should be done to lighten the task of the reader; the notation and reference system should be carefully thought out. Every paper should contain an introduction summarizing the results as far as possible in such a way as to be understood by the non-expert.

All other correspondence should be addressed to the Managing Editor. G. áe B. Robinson, University of Toronto.

The Journal is published quarterly. Subscriptions should be sent to the Managing Editor. The price per volume of four numbers is $\$ 8.00$. This is reduced to $\$ 4.00$ for individual members of recognized mathematical societies.

Published for

THE CANADIAN MATHEMATICAL CONGRESS

by the

UNIVERSITY OF TORONTO PRESS 